City University of New York (CUNY) CUNY Academic Works

\title{
AIDS Information in Periodical Indexes: A Problem of Exclusion
}

Polly Thistlethwaite

cUNY Graduate Center

\section{How does access to this work benefit you? Let us know!}

More information about this work at: https://academicworks.cuny.edu/gc_pubs/35

Discover additional works at: https://academicworks.cuny.edu

This work is made publicly available by the City University of New York (CUNY).

Contact: AcademicWorks@cuny.edu 


\section{AIDS Information in Periodical Indexes: A Problem of Exclusion}

\section{Polly Thistlethwaite}

Indexing companies and database search services are contributing to the epidemic of ignorance surrounding HIV and AIDS. They are failing us, even killing us. Doctors, patients, students, and researchers seeking information about HIV are offered access only to a narrow range of mainstream and professional publications through the leading indexes. And, while a certain slate of periodicals is represented over and over by rival indexes, gay/lesbian periodicals and community-based health publications containing vital, often vanguard HIV/AIDS information, are systematically excluded from mainstream indexes and database search services. This article offers a critique of current indexing practices of AIDS-related periodical literature and suggests strategies to remedy the situation.

The lack of indexing of gay/lesbian and certain other community-based publications reflect distinctions librarians and indexers apply to collection building and bibliographic access. These constructions distinguish mainstream from alternative publications, core requirements from peripheral options. Blunt and biased, these distinctions are used to define necessary from unnecessary publications, legitimate from illegitimate titles, authoritative from controversial ones.

Information specialists have not just snatched these definitions from out of the blue. They lie deeply embedded in Western politics and culture, reflected in our media, government, and religious institutions defining mainstream and alternative "lifestyles," normal from deviant sexual behavior, innocent from deserving people with AIDS. They are essentially the same dichotomies that have exacerbated the HIV epidemic, reassuring the "normal," righteous, heterosexual so-called "general population" that they are safe from, or at most, "innocent victims" of HIV while ignoring and condemning the queers and IV drug users who have brought this plague upon themselves. After all, as Nancy Reagan might say, they could've just said No.

Members of the American Library Association's Gay and Lesbian Task Force believe that librarians and library users must call these prejudicial distinctions into question and demand that indexers provide access to a fuller, more useful, and less distorted range of AIDS information. The Journal of Homosexuality, indexed in twenty-two places, can no longer serve as the single token gay periodical listed in popular and academic indexes.

\section{What the Mainstream Press Does and Does Not Do}

AIDS activists have documented the loathsome lack of mainstream media coverage of AIDS in the first crucial stages of the epidemic and the ways in which media neglect continues today (See Larry Kramer's Reports From the Holocaust, New York: St. Martin's, 1989 and Simon Watney's Policing Desire: Pornography, AIDS, and the Media, Minneapolis: University of Minnesota Press, 1987). One criticism often voiced by AIDS activists is that mainstream media have placed disproportionate focus on AIDS as a threat to the "general population," by featuring and sensationalizing the so-called "innocent" victims of HIV (e.g. babies of HIV-positive mothers; Ryan White who contracted HIV via transfusion; and Kimberly Bergalis who has filed for damages alleging her gay dentist infected her with HIV). Scarce, even absent, are the stories about HIV-positive women who are not mothers; the 
portraits of gay men and drug users not as pitiful victims, but as heroes and heroines waging their battles against the virus; the careful examinations of the questions posed by the late David Acer, Kimberly Bergalis' gay dentist and the first health care provider accused of infecting a patient with HIV, mode of transmission still unexplained. In much of mainstream media, gays, bisexuals, prostitutes, and drug users are depicted and dismissed as vectors of HIV transmission to an innocent, unsuspecting general population.

\section{Why We Need Access to the Gay/Lesbian Press}

In contrast, the gay and lesbian media have generated a powerful critique of the biases reflected in mainstream AIDS reporting (one that should be extended to periodical indexes as well). AIDS activists, dismissed by even liberal media as a special interest group rather than "experts," use the gay/lesbian and community-based press heavily, at times exclusively, to respond to AIDS-related government policy, to publicize drug trial and treatment news, to report on AIDS demonstrations, and to formulate political critiques and strategies. AIDS activism has, from its beginnings, shaped and reflected a gay/lesbian liberation agenda, one that must be recognized and understood by doctors, researchers, therapists, academics, indeed, any serious student of the epidemic. As librarians, should we allow the gay/lesbian press to continue to be such an under-consulted source of AIDS information, we would be complicit with a most insidious form of censorship.

As a result of a letter-writing campaign beginning in the summer of 1990, the American Library Association's Gay and Lesbian Task Force (GLTF) convinced Gale Research, Inc. to add gay/lesbian titles to Book Review Index. Beginning in 1991, Book Review Index promises to include reviews from Lambda Book Report, Out/Look, and The Advocate. The Information Access Company has said it will add The Advocate, Out/Look, Christopher St., and The Journal of Homosexuality to Magazine Index, InfoTrac, and its new Academic Index. In doing so, both companies will improve access to information about HIV/AIDS and gays and lesbians. The H.W. Wilson company, however, has failed to respond to the GLTF's efforts.

Since H.W. Wilson indexes are the most widely used of their kind, the GLTF has focused lobbying efforts in their direction (see Sidebar). In addition, the GLTF will lobby Dialog, SilverPlatter, BRS, MedLine, and others should attempt to expand and diversify the ground they cover instead of replicating what they and their competitors have already accomplished. To truly improve access to information about HIV/AIDS, online and CDROM databases must provide access to periodicals unindexed in any electronic format, for example The Alternative Press Index (which currently indexes eight gay and/or lesbian periodicals), Index to Black Periodicals, Hispanic American Periodicals Index, Left Index, and Women Studies Abstracts on disc or online. Like mainstream indexes, most specialized "community press" indexes must improve coverage of lesbian/gay periodicals. Improved indexing and database search services are desperately needed to facilitate fuller medical, academic, and popular understandings about HIV/AIDS. We must be equipped with a full range of knowledge, and we must be allowed unencumbered access to it, in order to put an end to the AIDS epidemic. 
A Few HIV/AIDS and Gay/Lesbian Press Titles Underrepresented by Indexes and Database Search Services

The Advocate. 1967-. Bi-w. \$45. Liberation Publications, Inc., 6922 Hollywood Blvd., Los Angeles, CA 90026. Ed: Richard Rouilard. Circ. 250,000. Indexed: Alternative Press Index.

This longest-lived U.S. gay publication has just received the attention of mainstream indexers. Retrospective indexing is available from the publisher; retrospective mainstream coverage would provide a fuller record of the past 20-year evolution of gay sensibility.

The Directory of AIDS Clinical Trials. 1988-. Q. Free. AIDS Treatment Registry, 259 W. 30th St., New York, NY 10001. Ed: James D'Eramo. Circ: 3,000. Indexed: Nowhere.

A comprehensive compilation of clinical trials available in the New York/New Jersey region, two states with the leading rates of U.S. AIDS cases. Working closely with activist and community health networks, ATR often provides fuller, clearer, and more critical evaluations than the highly technical directories available through the government's National AIDS Information Clearinghouse.

BLK. 1989-. M. \$18. BLK Publishing Company, Box 83912, Los Angeles, CA, 90083. Ed: Alan Bell. Circ: 31,000. Indexed: Alternative Press Index.

A national Black lesbian and gay newsmagazine, $B L K$ contains reporting and analysis of many of our movement's strongest voices. BLK should be indexed by popular periodical indexes and by Black Periodicals Index. We also recommend that Black/Out, a first rate publication from the National Coalition of Black Lesbians and Gays last published in 1988, be retrospectively covered as well.

The Body Positive. 1987-. M. \$35. Body Positive, 2095 Broadway, Suite 306, New York, NY 10023. Ed: Michael Slocum. Indexed: Nowhere.

A primary community-based publication read and published by PWAs and AIDS activists, containing articles on a wide variety of topics: women and HIV, treatment options, social resources for PWAs. Some articles in Spanish. Appropriate for popular periodical indexes, social science and social service indexes, medical indexes.

CRI Treatment and Research Forum. 1990-. M. Contribution. Community Research Initiative, 31 W. 26th St., New York, NY 10010. Circ: 10,000. Indexed: Nowhere.

All HIV/AIDS treatment is experimental. It is important, therefore, for people and their health care providers to have a good variety of current, thorough, critical information available to make treatment decisions. Appropriate for medical, social service, social science indexes.

Gay Community News. 1973-. W. \$55. GCN, 62 Berkeley St., Boston, MA 02116.

Ed: Frank Strona. Circ: 15,000. Indexed: Alternative Press Index.

Since 1973 GCN has been the newsweekly of choice for the Gay and Lesbian activist community. GCN is a model cooperative effort between lesbians and gays; lesbian issues are well-reported. GCN should be a mainstay for every popular periodical index.

Healthsharing: A Canadian Women's Health Quarterly. 1979-. Q. \$22. Women Healthsharing, 14 Skey Lane, Toronto, Ont., M6J 3S4. Ed. Amy Gottleib. Circ: 5,000. Indexed: Alternative Press Index, Feminist Periodicals, Studies on Women Abstracts.

An excellent grassroots women's health journal that warrants wider coverage in medical and social service indexes. 
Lambda Book Report. 1987-. Bi-m. \$18. LBR, 1625 Connecticut Ave., NW, Washington, DC 20009. Ed: Jane Troxell. Circ: 110,000. Indexed: Alternative Press Index, Book Review Index.

Why won't the H.W. Wilson company include this publication in Book Review Digest?

Lesbian Contradiction. 1982-. M. \$19. LesCon, 584 Castro St., \#263,

San Francisco, CA 94114. Circ: 2,000. Indexed: Alternative Press Index.

A leading, nationally distributed Lesbian publication known for its back and forth about gay, lesbian, and feminist politics. Appropriate for popular periodical indexes and Women Studies Abstracts.

Lesbian News. 1975-. M. \$20. LN, 7985 Santa Monica Blvd., Suite 109-13, West Hollywood, CA 90046. Ed: Deborah Bergman. Circ: 8,000. Indexed: Nowhere.

Lesbian News has emerged as a leading source of gay/lesbian information, with a leaning focus on LA area issues. Like, LesCon, $L N$ should be included in popular periodical indexes and Women Studies Abstracts.

New York Native. 1980-. W. \$49. That New Magazine, Inc., Box 1475, New York, NY 10008. Ed: Charles Ortleb. Circ: 16,000. Indexed: Nowhere.

From the beginning of the AIDS epidemic, The Native has provided reporting that is passionate and often unique. The Native has lost subscribers to the rival OutWeek as editor Ortleb follows a tangential, yet significant, path of AIDS/HIV reporting. Popular periodical indexes should have picked up The Native years ago.

Out/Look. 1988-. Q. \$29. Out/Look Foundation, 2940 16th St., Suite 319, San Francisco, CA 94103. Ed: Jan Zita Grover. Circ: 18,000. Indexed: Alternative Press Index.

A fine, well-edited journal that features the considered writing of known and unknown lesbians and gays. Blacks, Latins, Asians, Native Americans and lesbians are represented among the contributors. Writing covers political, cultural, literary, scientific, and artistic topics. Out/Look should be included in no fewer than a slew of popular and academic periodical indexes. It has just received attention from Information Access indexes.

OutWeek. 1990-. W. \$100. OutWeek Publishing Corp., 159 W.25th St., New York, NY 10001. Ed: Gabriel Rotello. Indexed: Nowhere.

OutWeek, the most talked-about queer periodical to hit the newsstands this decade, has altered the balance of the gay/lesbian press. Formed amidst the spirit and sensibility of the New York AIDS activist group ACTUP, OutWeek presses gay/lesbian political issues inside as well as outside our communities. OutWeek contains writing relevant to nearly every student inquiry about HIV/AIDS activism and treatment. It is a very important publication and should be included in every popular periodical index.

PWA Coalition Newsline. 1989-. M. Free. PWA Coalition, Inc., 31 West 26th St., New York, NY 10010. Indexed: Nowhere.

Contains political/social analysis, essays, and treatment reports written by and for PWAs. Newsline should be indexed in medical and social service indexes. 


\section{Sidebar: Index Activism: How Librarians and Library Users Can Respond}

In June 1990, the American Library Association's Gay and Lesbian Task Force (GLTF) began correspondence with several leading indexing companies to convince them to include gay and lesbian publications in various popular and specialized periodical indexes. Our letters stated, in part, that the exclusion of gay and lesbian voices from conventional periodical indexes encumbers popular access to important commentary and impedes lesbian and gay participation in political and cultural debate. Gale Research, Inc., publishers of Book Review Index and Information Access Company, producers of Magazine Index, InfoTrac, and Academic Index, responded promptly by announcing intended additions of gay and lesbian press titles to their index services. The H. W. Wilson Company, however, has failed to respond to GLTF concerns.

In January 1991 at an open ALA Mid-winter meeting of the RASD Wilson Indexes advisory committee, George Lewicky, Wilson's vice-president and director of Indexing Services, informed GLTF members that a winter 1990 review of The Reader's Guide to Periodical Literature resulted in the addition of twenty new titles to the index, none of them gay or lesbian. When asked by GLTF members why Wilson continued to exclude gay and lesbian publications from Reader's Guide, Lewicky responded that Wilson reviewers found no gay/lesbian periodical "appropriate" for inclusion.

Write or phone the H.W. Wilson Company. Tell President Weins to stop the exclusion of the gay/lesbian press from Reader's Guide and other Wilson indexes. Consult this article's bibliography, and add your own recommendations for particular Wilson indexes. Urge indexers to add lesbian press titles and publications from Black, Latin, Asian, and Native American communities so to fairly represent the diversity of voices within gay and lesbian communities. Producers of periodical indexes can remedy the substantial inadequacies in their services stemming from the homophobia, racism, and sexism characterizing their irresponsibly narrow versions of information access tools. Since Wilson has refused to correct the bias in their indexes, librarians and library users must act to force them to do so.

Lew Weins, President

H.W. Wilson Company

950 University Ave.

Bronx, NY 10452

Phone: 212/588-8400, extension 2206 